\title{
Review: Ocular Complications of Mosquito-Transmitted Diseases
}

\author{
Bhagya Segu, OD, MPH, FAAO \\ Staff Optometrist, \\ Michael E. DeBakey \\ Veterans Administration \\ Medical Center
}

\author{
Nicole Auchter Riese, OD \\ Staff Optometrist, \\ Beaumont Veterans \\ Administration \\ Outpatient Clinic
}

\section{Kim Thien Huong Nguyen, OD \\ Optometric Student \\ Externship Coordinator, \\ Staff Optometrist, \\ Katy Veterans Administration \\ Outpatient Clinic}

\section{Michael Leung, OD \\ Staff Optometrist, \\ Richmond Veterans \\ Administration \\ Outpatient Clinic}

Pat Segu, OD, FAAO

University of Houston

College of Optometry

\begin{abstract}
The World Health Organization estimates that 1 billion cases of infectious disease originate from vector transmission, resulting in several million deaths annually. Mosquitos are the primary vector for multiple diseases in humans that cause self-limiting to sight-threatening ocular complications and significant systemic illness. The 2015-2016 outbreak of the mosquitoborne Zika virus in North and South America brought to the forefront how quickly mosquitoes can spread disease between continents, especially among vulnerable patient populations. Optometrists should be familiar with the associated ocular complications in order to effectively diagnose, co-manage, treat, and educate patients who have been infected by mosquito-borne disease. This paper reviews the ocular manifestations of mosquito-transmitted diseases including Zika virus, West Nile virus, Malaria, Dengue fever, Chikungunya, and Dirofilaria.
\end{abstract}

\section{KEY WORDS:}

Mosquito-borne diseases, Ocular dirofilariasis, Zika virus, West Nile virus, Cerebral Malaria, Dengue fever, Chikungunya, Dirofilaria, Ocular manifestations

\section{INTRODUCTION}

Mosquitoes are known vectors for certain infectious diseases that can be transmitted from animals to humans or between humans. When feeding on the blood of an infected organism, the mosquito can acquire a virus or a parasite, which can then be injected into another human during a subsequent blood meal. Aided by factors such as the globalization of travel, environmental challenges like climate change, and the urbanization of rural areas, mosquito-transmitted diseases such as Dengue fever, Chikungunya and West Nile virus have been found for the first time in certain countries. ${ }^{1}$ The 2016 outbreak of the mosquito-borne Zika virus in North and South America exemplifies how quickly mosquitoes can spread disease between continents, causing significant health risks in vulnerable patient populations, such as pregnant women. ${ }^{2}$ With this increase in the prevalence of mosquito-borne disease, it is imperative for healthcare providers to stay informed about the associated clinical signs and complications. This paper reviews published literature on the ocular manifestations of mosquitotransmitted diseases including Zika virus, West Nile virus, malaria, Dengue fever, Chikungunya, and Dirofilaria (summarized in Table 1). 


\begin{tabular}{|c|c|c|c|c|}
\hline Disease & Transmission & $\begin{array}{l}\text { Endemic areas with } \\
\text { active transmission }\end{array}$ & $\begin{array}{l}\text { Vaccine } \\
\text { available }\end{array}$ & Ocular manifestations \\
\hline $\begin{array}{l}\text { Zika virus } \\
(\text { ZIKV) }\end{array}$ & $\begin{array}{l}\text { Mosquito Vector: } \\
\text { Aedes aegypti or Aedes } \\
\text { albopictus mosquitos } \\
\text { - Sexual intercourse with } \\
\text { an infected individual } \\
\text { - Maternal-fetal transmission }\end{array}$ & $\begin{array}{l}\text { Mexico } \\
\text { Central America } \\
\text { South America } \\
\text { New Guinea }\end{array}$ & No & $\begin{array}{l}\text { Fetal } \\
\text { Focal pigment mottling of the retina } \\
\text { Chorioretinal atrophy } \\
\text { Macular atrophy } \\
\text { Cataract } \\
\text { Asymmetrical eye sizes } \\
\text { Intraocular calcifications } \\
\text { Optic nerve abnormalities } \\
\text { Lens subluxation } \\
\text { Adults } \\
\text { Guillain-Barré syndrome, which is } \\
\text { associated with various ocular muscle } \\
\text { palsies and non-purulent conjunctivitis }\end{array}$ \\
\hline $\begin{array}{l}\text { West Nile } \\
\text { virus } \\
\text { (WNV) }\end{array}$ & $\begin{array}{l}\text { Mosquito vector: } \\
64 \text { types of mosquito species } \\
\text { carry WNV. The most } \\
\text { common species are the } \\
\text { Aedes and Culex mosquitoes. } \\
\text { Virus is acquired after a } \\
\text { mosquito feeds on an infected } \\
\text { bird. } \\
\text { - Low risk of maternal-fetal } \\
\text { transmission or through } \\
\text { blood transfusions. }\end{array}$ & $\begin{array}{l}\text { Europe, Middle East, } \\
\text { West Asia, North } \\
\text { America, South } \\
\text { America, } \\
\text { and Australia }\end{array}$ & No & $\begin{array}{l}\text { Retinal hemorrhages } \\
\text { Vitritis } \\
\text { Perivascular sheathing } \\
\text { Vasculitis } \\
\text { Disc edema } \\
\text { Optic atrophy } \\
\text { Vascular occlusion } \\
\text { Sixth nerve palsy } \\
\text { Uveitis } \\
\text { Ocular complications associated with } \\
\text { meningoencephalitis secondary to WNV } \\
\text { Acute hemorrhagic conjunctivitis } \\
\text { Bilateral subconjunctival hemorrhages } \\
\text { Nystagmus } \\
\text { Fetal } \\
\text { Chorioretinal involvement }\end{array}$ \\
\hline Malaria & $\begin{array}{l}\text { Mosquito vector: } \\
\text { Anopheles mosquito } \\
\text { • Blood transfusion, organ } \\
\text { transplant, or the shared } \\
\text { use of needles or syringes } \\
\text { contaminated with blood } \\
\text { - Maternal-fetal transmission }\end{array}$ & $\begin{array}{l}\text { Highest transmission } \\
\text { is found in Africa } \\
\text { south of the } \\
\text { Sahara and in } \\
\text { parts of Oceania } \\
\text { such as Papua } \\
\text { New Guinea }\end{array}$ & $\begin{array}{l}\text { Vaccine } \\
\text { clinical } \\
\text { trials are } \\
\text { ongoing } \\
\text { Antimalarial } \\
\text { drugs are } \\
\text { available }\end{array}$ & $\begin{array}{l}\text { Ocular complications are generally } \\
\text { associated with cerebral malaria (CM) } \\
\text { Retinal whitening in the periphery and } \\
\text { macula (sparing the fovea) } \\
\text { Peripheral orange or white vessel } \\
\text { discoloration } \\
\text { Roth's spots } \\
\text { Papilledema } \\
\text { Cotton wool spots }\end{array}$ \\
\hline $\begin{array}{l}\text { Dengue } \\
\text { fever (DF) }\end{array}$ & $\begin{array}{l}\text { Mosquito vector: Aedes } \\
\text { aegypti mosquito } \\
\text { - Dengue cannot be spread } \\
\text { directly from person to } \\
\text { person }\end{array}$ & $\begin{array}{l}\text { Tropical countries } \\
\text { such as Southeast } \\
\text { Asia, India, and } \\
\text { the American } \\
\text { Tropics }\end{array}$ & No & $\begin{array}{l}\text { Retinal hemorrhages } \\
\text { Macular edema } \\
\text { Foveolitis } \\
\text { Vasculitis } \\
\text { Optic neuropathy } \\
\text { Subconjunctival hemorrhages } \\
\text { Uveitis } \\
\text { Angle closure glaucoma }\end{array}$ \\
\hline Chikungunya & $\begin{array}{l}\text { Mosquito vector: Aedes } \\
\text { aegypti and Aedes albopictus } \\
\text { mosquitos } \\
\text { - Rarely from mother to } \\
\text { newborn around the time of } \\
\text { birth } \\
\text { - While, in theory, the virus } \\
\text { could be spread through a } \\
\text { blood transfusion, to date, } \\
\text { there are no known reports. }\end{array}$ & $\begin{array}{l}\text { Africa, Asia, } \\
\text { Europe, islands } \\
\text { in the Caribbean, } \\
\text { the Indian and } \\
\text { Pacific Oceans }\end{array}$ & No & $\begin{array}{l}\text { Conjunctival injection } \\
\text { Photophobia } \\
\text { Anterior and posterior inflammation } \\
\text { Secondary complications of ocular } \\
\text { inflammation } \\
\text { Sixth nerve palsy } \\
\text { Central retinal artery occlusion (CRAO) } \\
\text { Exudative retinal detachment } \\
\text { Glaucoma }\end{array}$ \\
\hline $\begin{array}{l}\text { Dirofilaria } \\
\text { repens (DR) }\end{array}$ & $\begin{array}{l}\text { Mosquito Vector: } \\
\text { Aedes, Anopheles, Mansonia, } \\
\text { or Culex mosquitos }\end{array}$ & $\begin{array}{l}\text { Warm climates on } \\
\text { various continents, } \\
\text { in Europe mainly } \\
\text { in Mediterranean } \\
\text { countries }\end{array}$ & No & $\begin{array}{l}\text { Ophthalmic subcutaneous lesions } \\
\text { usually causing pain and redness } \\
\text { Eyelid } \\
\text { Periorbital } \\
\text { Subconjunctival } \\
\text { Subtenons } \\
\text { Intraocular }\end{array}$ \\
\hline
\end{tabular}




\section{ZIKA VIRUS}

The Zika virus (ZIKV) is a flavivirus that is transmitted primarily by Aedes aegypti mosquitoes and was first identified in humans in 1952. ${ }^{2}$ The 2016 ZIKV epidemic in Brazil likely originated from French Polynesia and subsequently spread from South America to Central and North America. If infected, a person may display symptoms such as fever for a short amount of time, rash, joint pain, or conjunctivitis. ${ }^{2}$ In February of 2016, the World Health Organization considered the ZIKV outbreak to be a "Public Health Emergency of International Concern" based on the microcephaly and neurological disorders associated with the disease. ${ }^{3}$

Pregnant women are most susceptible to maternal-fetal transmission when exposed to ZIKV in the first or second trimester. Circumstantial evidence suggests that fetal manifestations of ZIKV infection may be induced by cholestatic liver damage resulting in the leakage of toxic concentrations of vitamin A compounds (Hypervitaminosis A) into the maternal and fetal circulation. Hypervitaminosis A is speculated to cause overall fetal growth arrest, microcephaly, and other congenital anomalies. Due to the general association of microcephaly and ocular complications, comprehensive eye examinations are recommended in microcephalic infants. Unilateral and bilateral retinal pathology has been documented in microcephalic infants, most commonly as focal pigment mottling of the retina and chorioretinal atrophy. Other reported ophthalmic findings have included macular atrophy, iris coloboma with lens subluxation, cataract, asymmetrical eye sizes, intraocular calcifications, and various optic nerve abnormalities. ${ }^{4}$ It has also been shown that ZIKV can cause Guillain-Barré syndrome, an autoimmune disorder that can be associated with various ocular muscle palsies and non-purulent conjunctivitis in adults. ${ }^{5}$

ZIKV can be detected by performing real-time reverse transcription-polymerase chain reaction (rRT-PCR) on serum or urine, or IgM testing on serum; however, these methods are not readily available in countries where the condition is prevelant. ${ }^{2}$ Since there is no ZIKV vaccine or specific treatment for ZIKV, women living in endemic areas should consider these risks before conceiving and avoid travelling to regions where disease outbreak is evident. ${ }^{6}$ ZIKV can also be transmitted through sexual intercourse with an infected partner since the virus remains in semen longer than in any other body fluid; therefore, appropriate precautions must be taken. ${ }^{2}$

\section{WEST NILE VIRUS}

A variety of mosquitoes transmit the flavivirus which is responsible for West Nile virus (WNV) from infected birds to humans. The virus first entered the western hemisphere in 1999 and is now prevalent in North America, especially during the summer months. It is estimated that $80 \%$ of WNV-infected individuals are asymptomatic; while $20 \%$ may exhibit flu-like symptoms, exact statistics vary.,8 Patients infected by WNV are at risk of developing devastating neurological disease, which may manifest 3-14 days after infection. Clinical symptoms can range from generalized muscle weakness to high fever, stiff neck, and even convulsions. Adults aged 50 and older and individuals who are immunocompromised have a higher chance of developing neurological complications from WNV. ${ }^{7}$

A multitude of ocular manifestations have been reported, including, but not limited to, retinal hemorrhages, vitritis, perivascular sheathing, vasculitis, disc edema, optic atrophy, vascular occlusion, sixth nerve palsy, and uveitis. ${ }^{8-10}$ In less than $1 \%$ of cases, an infected individual can develop WNV meningoencephalitis, which has been documented in the literature to be associated with ocular complications such as acute hemorrhagic conjunctivitis, bilateral subconjunctival hemorrhages, and nystagmus. ${ }^{11}$ Chorioretinal involvement can also develop in a fetus via intrauterine virus transmission. One such case was documented in a newborn whose mother had contracted WNV two months before delivery. ${ }^{12}$ Current management of WNV includes pain control for headaches, anti-emetics, rehydration for associated nausea and vomiting, clinical monitoring for development of elevated intracranial pressure or autonomic dysfunction, and seizure control, if needed..$^{13}$

\section{MALARIA}

Malaria is endemic to sub-Saharan Africa, where children are most vulnerable to contracting the disease due to their immature immune systems. It is mainly transmitted by the Anopheles mosquito, but can also be passed via a blood transfusion, an organ transplant, or the shared use of contaminated needles or syringes since the parasite resides in the red blood cells of an infected individual. Congenital malaria occurs when the parasite is transmitted before or during delivery from a mother to her child. The first presentation of clinical signs often occurs 10-15 days following infection by a mosquito bite. In the early stages of infection, the diagnosis of malaria may be difficult to make because of the generalized clinical presentation of fever and vomiting. ${ }^{1}$ 
Several parasites in the Plasmodium genus infect humans with malaria, including $P$. falciparum, $P$. vivax, $P$. ovale, and $P$. malariae. ${ }^{14}$ P. falciparum causes cerebral malaria (CM), which has a high rate of mortality and is characterized by coma and long-term neuro-cognitive impairments. ${ }^{15}$ Some ocular complications can be noted with CM, since the retinal and cerebral vasculature are direct extensions of one another; therefore, monitoring retinal changes can provide an understanding of the neurological pathogenesis of CM and aid in determining the patient's prognosis and, perhaps, better treatment strategies. ${ }^{16}$

CM retinopathy shows retinal whitening patterns and vessel changes that are unique to the disease. Both are mainly found in the peripheral retina with a white or orange discoloration of the vessels. Other retinal findings include cotton wool spots, papilledema, and Roth's spots. ${ }^{16,17}$ Due to the distinctive retinal presentation of the disease, these findings can be useful in confirming the diagnosis of CM. In addition, the severity of retinopathy and papilledema may be an indicator of disease prognosis. ${ }^{15}$ If CM develops, the treatment of choice is the water-soluble artemisinin derivative artesunate and adjunctive supportive management of malaria complications. ${ }^{14,18,19}$

Currently, there are no effective malarial vaccines and multi-drug resistance is prevalent; therefore, travelers destined for endemic regions are recommended to begin prophylactic treatment prior to departure and continue treatment for a period of time after returning home. The recommended medications for prophylaxis and their associated treatment time frames vary depending on the country of travel. ${ }^{14}$

\section{DENGUE FEVER}

Dengue fever (DF) is a self-limiting condition transmitted by the Aedes aegypti mosquito. Female mosquitoes infected with the dengue flavivirus are endemic to tropical countries, such as Southeast Asia, India, and the American tropics. As the name implies, infected individuals suffer from an acute onset of fever along with other general symptoms, such as malaise, sore throat, and headache. ${ }^{20,21} \mathrm{DF}$ is potentially life-threatening in a small proportion of infected individuals and can cause severe hemorrhages, organ dysfunction, or plasma leakage. Patients with DF may also have a myriad of symptomatic anterior and posterior segment ocular complications resulting in blurred vision and scotomas. Such symptoms may indicate thrombocytopenia and a need for early, aggressive treatment; however, there is no specific therapy for DF itself. ${ }^{21}$

Blurry vision is the most commonly reported dengue-related ocular symptom, followed by scotoma and ocular pain, which can be diffuse or retrobulbar. The ocular complications of this disease are more commonly found within the posterior segment, particularly involving the macula. Manifestations include retinal hemorrhages, macular edema, foveolitis, vasculitis, vascular occlusion and optic neuropathy. Anterior segment complications include subconjunctival hemorrhages, uveitis with and without ciliary congestion, and shallowing of the anterior chamber angle with the risk of acute angle closure. Patients with severe vision loss or bilateral involvement can be treated with systemic steroids, and occasionally immunoglobulins, to minimize inflammatory damage; however, most dengue-related ophthalmic complications resolve without treatment. ${ }^{20}$ Since no vaccines or specific medications are available to treat DF, precautions should be taken when traveling to areas where the virus is endemic. ${ }^{22}$

\section{CHIKUNGUNYA}

Chikungunya fever is caused by the Chikungunya virus and is most often spread by Aedes aegypti and Aedes albopictus mosquitoes. After a quiescent period, this virus re-emerged over the last decade in several regions including Africa, North and South America, Asia, Europe, and the Indian and Pacific Oceans. ${ }^{23}$ The symptoms associated with this infection include an abrupt onset of severe joint pain, which can be debilitating, fever, chills, headache, muscle ache, and rash. The onset of symptoms typically occurs 4 to 8 days following infection by the mosquito.?

Ocular inflammation is a documented complication of Chikungunya fever and commonly presents as granulomatous or non-granulomatous anterior uveitis. Infected individuals may also present with conjunctival injection and photophobia. There have also been reports of keratitis, episcleritis, retinitis with vitritis, neuroretinitis, multifocal choroiditis, panuveitis, and optic neuritis. Secondary complications of ocular inflammation include sixth nerve palsy, central retinal artery occlusion, exudative retinal detachment, and glaucoma. ${ }^{24}$ Chikungunya fever-related ocular inflammation responds well to corticosteroid therapy over a period of 6-12 weeks and, if treated early, can resolve with a good visual outcome. ${ }^{24,25}$ Management of systemic symptoms includes pain reduction and dehydration prevention. 
There is no vaccine to prevent infection by the Chikungunya virus; therefore, to limit the spread of the virus, infected individuals should take precautions against mosquito bites. The virus is present in the blood during the first week of infection and can be transmitted to mosquitoes and other people during that time. ${ }^{23}$

DIROFILARIASIS

Human dirofilariasis is a rare vector-borne zoonotic disease that is commonly caused by Dirofilaria repens and Dirofilaria immitus. D. repens is a subcutaneous parasite of domestic animals in warm and moist climates. The disease is transmitted to humans through the bite of an infected Aedes, Anopheles, Mansonia or Culex mosquito. ${ }^{26-28}$ Symptoms of $D$. repens include benign subcutaneous lesions on the face, chest wall, upper arms, thighs, abdominal wall, and male genitalia. Between 30-35\% of D. repens-related infections occur in the ocular regions.

Most cases of ocular dirofilariasis involve infestations of the periocular tissue. In approximately $60 \%$ of the human cases reported, the parasites were located under the conjunctiva within nodules or cysts that grow over time. ${ }^{29}$ Lesions may also be found on the eyelid where they have been reported to cause preseptal cellulitis. Symptoms depend on the site of the infection, but typically include pain and redness. ${ }^{27}$ The treatment for ocular dirofilariasis is complete excision of the lesion. Definitive diagnosis is confirmed by histopathologic and microscopic examination of the surgically excised worm. ${ }^{30}$

\section{PREVENTION}

The number of humans infected by mosquito-transmitted diseases may increase secondary to multiple factors such as the globalization of travel, and social and environmental issues. ${ }^{1}$ Early containment of outbreaks is key to reducing the transmission and spread of these diseases. The World Health Organization continues to assist countries through enhanced disease surveillance, the development of new mechanisms to reduce the spread of disease, and education on disease recognition.

The ocular manifestations caused by mosquito-borne diseases can range from self-limiting to vision-threatening. Optometrists play an important role in the clinical co-management of patients infected by mosquito-borne illness, in collaboration with infectious disease specialists. To aid in early diagnosis and minimize morbidity, optometrists should inquire about recent travel to any endemic regions for patients exhibiting systemic symptoms, such as a fever with an associated complaint of blurred vision and/or ocular discomfort.

Unfortunately, no vaccines or drugs are available to treat most of these mosquito-transmitted diseases; therefore, those travelling to high-risk countries should be educated on mosquito bite prevention, including the use of Environmental Protection Agency (EPA)-approved mosquito repellants, mosquito bed nets, and window/door screens, and ensuring that both indoor and outdoor environments do not support standing water where mosquitoes typically lay their eggs. ${ }^{22,31,32}$ Furthermore, vulnerable patient populations, such as pregnant women, young children, and the immunocompromised, should avoid travel to areas of disease outbreak. In cases where travel is unavoidable, awareness of the common manifestations of a mosquito-transmitted disease is imperative so that infected individuals will seek immediate medical attention if they experience any correlating symptoms. ${ }^{1,2,7} \bullet$ 


\section{REFERENCES}

1. World Health Organization. Vector-borne diseases. 2016. accessed 28 Jan 2017 <http://www.who.int/mediacentre/factsheets/fs387/en/>.

2. Centers for Disease Control and Prevention. 2016. accessed 28 Jan 2017 <https:/www.cdc.gov/zika/about/index.html>.

3. World Health Organization. WHO statement on the first meeting of the International Health Regulations (2005) (IHR 2005) Emergency Committee on Zika virus and observed increase in neurological disorders and neonatal malformations. n.d. accessed 26 Mar 2017 $<$ http://www.who.int/mediacentre/news/statements/2016/1stemergency-committee-zika/en/>.

4. Mawson AR. Pathogenesis of Zika virus-associated embryopathy. BioRes Open Access 2016; 5(1): 171-6.

5. Cao-Lormeau V-M, Blake A, Mons S, et al. Guillain-Barré Syndrome outbreak associated with Zika virus infection in French Polynesia: a case-control study. Lancet 2016; 387(10027): 1531-9.

6. Jampol LM, Goldstein DA. Zika virus infection and the eye. JAMA Ophthalmol 2016; 134(5): 535.

7. World Health Organization. Mosquito-borne diseases. n.d. accessed 26 Mar 2017 <http://www.who.int/neglected_diseases/vector_ecology/mosquito-borne-diseases/en/>.

8. Chan C, Limstrom S, Tarasewicz D, Lin, S. Ocular features of Wes Nile virus infection in North America: A study of 14 eyes. Ophthalmology 2006; 113(9): 1539-46.

9. Kuchtey RW. Uveitis associated with West Nile virus infection. Arch Ophthalmol 2003; 121(11): 1648.

10. Bains HS, Jampol LM, Caughron MC, Parnell JR. Vitritis and chorioretinitis in a patient With West Nile virus infection.” Arch Ophthalmol 2003; 121(2): 205-7.

11. Malhotra K, Ramanathan RS, Synowiec A, Rana S. Rare ocular manifestation in a case of West Nile virus meningoencephalitis. Ann Indian Acad Neurol 2014; 17(1): 95-6. PMC. accessed 29 Jan 2017.

12. Alpert SG, Fergerson J, Noël LP. Intrauterine West Nile virus: ocular and systemic findings. Am J Ophthalmol 2003; 136(4): 733-5.

13. Sejvar JJ. Clinical manifestations and outcomes of West Nile virus infection. Viruses 2014; 6(2): 606-23. PMC. accessed 29 Jan 2017.

14. Centers for Disease Control and Prevention. Frequently Asked Questions (FAQs). 2016 accessed 28 Jan $2017<$ https://www.cdc. gov/malaria/about/faqs.html>.

15. Idro R, Marsh K, John CC, Newton CR. Cerebral malaria; mechanisms of brain injury and strategies for improved neuro-cognitive outcome. Pediatr Res 2010; 6(4): 267-74. PMC. accessed 29 Jan 2017.

16. Maude RJ, Dondorp AM, Abu Sayeed A, Day NP, White NJ, Beare NA. The eye in cerebral malaria: what can it teach us? Trans $R$ Soc Trop Med Hyg 2009; 103(7): 661-4. PMC. accessed 29 Jan 2017.

17. Essuman VA, Ntim-Amponsah CT, Astrup BS, et al. Retinopathy in severe malaria in Ghanaian children - overlap between fundus changes in cerebral and non-cerebral malaria. Malaria J 2010; 9: 232. PMC. accessed 29 Jan 2017.
18. Wah ST, Hananantachai H, Kerdpin U, Plabplueng C, Prachayasittikul V, Nuchnoi P. Molecular basis of human cerebral malaria development. Trop Med Health 2016; 44: 33. PMC. accessed 29 Jan 2017.

19. Çizmeci EA, Kelebek Girgin N, Ceylan I, Tuncel T, Alver O, Akalin $\mathrm{EH}$. Cerebral malaria treated with artemisinin in the intensive care unit: a case report. Iran J Parasitol 2016; 11(1): 116-20.

20. Yip VC, Sanjay S, Koh YT. Ophthalmic complications of dengue fever: a systematic review. Ophthalmol Ther 2012; 1(1): 2. PMC. accessed 29 Jan 2017.

21. Nagaraj KB, Jayadev C, Yajmaan S, Prakash S. An unusual ocular emergency in severe dengue. Middle East Afr J Ophthalmol 2014; 21(4): 347-9. PMC. accessed 29 Jan 2017.

22. Centers for Disease Control and Prevention. How to reduce your risk of dengue infection. 2012. accessed 28 Jan 2017. <https://www. cdc.gov/dengue/prevention/index.html>.

23. Centers for Disease Control and Prevention, Chikungunya Virus. 2015. accessed 28 Jan 2017. <https://www.cdc.gov/chikungunya/>.

24. G, Mahesh et al. A case of bilateral presumed chikungunya neuroretinitis. Indian J Ophthalmol 2009; 57(2): 148-50. PMC. accessed 29 Jan 2017.

25. Scripsema NK, Sharifi E, Samson CM, Kedhar S, Rosen RB. Chikungunya-associated uveitis and exudative retinal detachment. Retin Cases Brief Rep 2015; 9(4): 352-6.

26. Cielecka D, Zarnowska-Prymek H, Masny A, Salamatin R, Wesolowska M, Golab E. Human dirofilariosis in Poland: the first cases of autochthonous infections with Dirofilaria repens. Ann Agric Environ Med 2012;19:445-50.

27. Nagpal S, Kulkarni V. Periorbital dirofilariasis: a rare case from western India. J Clin Diagn Res 2016; 10(3): OD12-14. PMC. accessed 29 Jan 2017.

28. Centers for Disease Control and Prevention. Dirofilariasis. 2016. accessed 20 Mar 2017 <https://www.cdc.gov/dpdx/dirofilariasis/ index.html>.

29. Mirahmadi H, Maleki A, Hasanzadeh R, Ahoo MB, Mobedi I, Rostami A. Ocular dirofilariasis by Dirofilaria immitis in a child in Iran: A case report and review of the literature. Parasitol Int 2017; 66(1): 978-81.

30. Sassi SH, Abid L, Dhouib R, et al. Conjunctival dirofilariasis due to Dirofilaria Repens. A new Tunisian case. J Fr Ophtalmol. 2006;29:e5.

31. Benelli G, Jeffries CL, Walker T. Biological control of mosquito vectors: past, present, and future. Eds. Cuthbertson AGS, Riddick EW. Insects 2016; 7(4): 52. PMC. accessed 29 Jan 2017

32. Murray NE, Quam MB, Wilder-Smith A. Epidemiology of dengue: past, present and future prospects. Clin Epidemiol 2013; 5: 299-309. 